\title{
河川の一形態単位内における付着藻類群落, 特に珪藻群落の生息場所による違い
}

\author{
大塚泰介
}

\begin{abstract}
摘
要

京都市の賀茂川中流域の一形態単位内で, 珪藻群落の生息場所による違いを調 べた。試料は大礫の上面, 中磁, 砂, ツルヨシ Phragmites japonicaの匍甸茎から 每月 2 回ずつ， 1 年にわたって採集した。各生息場所ともに，付着藻類の季節的な 現存量変動は大きく，特に大砂上では変動が大きかった。中喕上の現存量は，砂 上, ツルヨシ上に比べて有意に小さかった。ほとんどの場合，珪藻群落の生息場 所間での種組成の違いは，同一生息場所内で同時に採集された 2 本の群落試料間 の種組成の違いよりも大きかった。従って，珪藻群落の種組成は生息場所間で異 なっていたと結論できる。大磁・砂・ツルヨシ上の珪藻群落の種組成は, 互いに 大きく異なっていたが，中磁上の種組成は他のいずれとも共通性があった。砂上 では Navicula spp.など, 運動性の高い珪藻が多かった。ツルヨシ上では夏期から 秋期にかけて Cocconeis placentula が著しく優占した。大礫上で Homoeothrix janthinaなど丵生糸状ラン藻が著しく優占した際には，Achnanthidium japonicum や Nitzschia hantzschiana が珪藻の中での優占種になることが多かっ た。
\end{abstract}

キーワード：珪藻, 群落, 生息場所, 河川

\section{序論}

珪藻群落の生息場所による違いに関する研究のうち，河川をフィールドにしたものはあ まり多くない。また，以下に述べるように結果もまちまちである。DoUGLAS（1958）は, 岩石上とコケ上では群落の種組成が異なっていたと報告した。一方で O'QuINN and SUlLIVAN（1983）は，岩石上と糸状緑藻上では違いが認められなかったと報告した。 STEVENSON and HASHIM（1989）は，きれいな（付着物の少ない）砂上，綿状沈殿物に覆わ れた砂上, 岩石上, 植物上, そしてプランクトン (流下藻) の群落を比較し, 綿状沈殿物 に犨われた砂上で他とやや種組成が異なった群落が見られたと報告した。KATOH (1991a) は新潟県の三国川を調查し, 礫上と落葉上の群落の種組成はほとんど違わなかったと報告 した。一方で К に異なっていたと報告した。

以上のような結果の相違には，河川ごとの環境の違いが影響していると考えられる。し かしそれ以外に, 生息場所間の違いを何と比較して解釈したかという問題が深く関係して いるように思われる。

一方で，河川の生息場所間での付着藻類群落の違いについて解釈するための材料は揃つ てきている。群落に影響を及ほすす微小環境については，流速（WENDKER, 1992 ; BIGGS and HICKEY, 1994), 礫の面（伊東，1959；上條・渡辺，1975）などに関方る報告がある。ま た人為的に付着基質を設置し，材質による珪藻群落の違いを研究した例もある（TUCHMAN 
and STEVENSON, 1980 ; 渡辺・鈴木，1989)。さらに河川の個々の生息場所における群落, すなわち岩表生群落 (例えば 後藤・根来, 1986；田中・渡辺，1990）, 砂裴生群落 (例え ば MOORE, 1977 ; KREJCI and Lowe, 1987), 植物表生群落 (例えば LUTTENTON and RADA, 1986 ；OH'TSUKA, 1998）の特徴に関する報告は多数ある。

本研究では珪藻群落が，河川の形態単位内の生息場所間でどのように異なるかを検討し た。河川中流域における代表的な 4 つ生息場所（大礫，中礫，砂，ツルヨシ）を相互比 較の対象とした。群落は水温の変化や出水などによって季節的に变化すると考之られたの で, 調査は年間を通じて行い, 群落の違いの季節性についても検討した。さらに, 種レべ ルでも生息場所による優占度の違いを明らかにした。

\section{方法}

\section{調査地点ならびに調查期間}

京都市北区の賀茂川中流域 $\left(35^{\circ} 04^{\prime} \mathrm{N}, 135^{\circ} 35^{\prime} \mathrm{E}\right.$; 海抜 $\left.115 \mathrm{~m}\right)$ で調查を行った。採集地 点は第 4 次河川で，河川形態は可児（1944）の分類法で Bb 型に相当する。河床は主に礫 で構成され, 両岸にはツルヨシ Phragmites japonica STEUDEL が繁茂している。集水域の大 部分がスギ Cryptimeria japonica D. Don. の植林地で，上流域には雲が畑，市原，鞍馬， 貴船などの集落がある。

調查は 1993 年 5 月 17 日から 1994 年 5 月 2 日までの 1 年間, 1 月に 2 回ずつ行った。 ただし 7 月の第 1 回の採集では，出水が続いて試料を十分に採集できなかったため，その 他の計 23 回の採集結果を分析に用いた。

水質は年間を通じてほぼ安定しており， $\mathrm{pH}$ が 7.0 9.2(13〜15 時の測定)，電気伝導度 が $77 \sim 113 \mu \mathrm{S} \mathrm{cm}^{-1}$ (以上, 1995 年 1 月 -1996 年 8 月の值), $\mathrm{NO}_{3}{ }^{-}-\mathrm{N}$ が $13 \sim 27 \mu \mathrm{g}$ at $\mathrm{N} \mathrm{l}^{-1}, \mathrm{PO}_{4}{ }^{3-} \mathrm{P}$ が $0.5 \sim 1.1 \mu \mathrm{g}$ at $\cdot \mathrm{P} \mathrm{l}^{-1}$ (以上, 調查期間の值) であった。付着藻類の成 長は，リンによって制限されていたと推察される（OHTSUKA，1998）。

1994 年 2 月にはすぐ上流の高橋の掛け替え工事が行われ, 約 1 力月にわたって濁水が流 れた。その際，河床にはシルトが堆積し，河川形態も平坦になるなど，河川環境はかなり の攪乱を受けた。

\section{群落試料の採集}

毎回の試料採集は同じ形態単位内で行い，(1)大碩，(2)中砶，(3)砂，(4)ッルヨシ匍匐茎, の 4 つ生息場所から，各 2 本ずつの試料を採集した。試料採集は以下の手順で行つた。 （1）大磁（粒径 64 256 $\mathrm{mm}$; 本研究では $100 \mathrm{~mm}$ 以上の碚を選んだ）：瀬の浮き石を採取 し，上面に $25 \mathrm{~cm}^{2}$ のゴム製の方形枠を当て，鉛筆で磁上に枠を描いた。そして，まず枠 の外側の付着物を台所用スポンジでこすり落として捨て, 続いて内側の付着物を蒸留水 で水洗しながら歯ブラシでこすり落として採集した。

付着藻類の群落は，碟の面によって違いがあることが報告されている（伊東，1959； 上條・渡辺，1975)。本研究における「大磁」は，綮密には大礫の上面のみを指している。

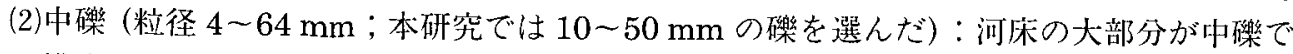
構成されている場所を選び, $10 \times 10 \mathrm{~cm}$ 程度の範囲から $25 \mathrm{~cm}^{2} の$ 才形枠が一杯になる

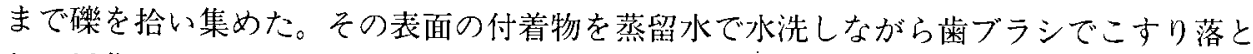

して採集した。

(3)砂（粒径 1/16－2 mm）：まず口径 $38 \mathrm{~mm}$ の自製の採砂器を砂底に $6 \mathrm{~cm}$ 程度の深さま で差し込み，側方から砂に手をつっこんで採砂器の底を押さえながら持ち_上げて砂を採 
集した。続いて採砂器のシリンダーを押して底のカの砂を捨て, 表面から $3 \mathrm{~cm}$ までの砂 だけを $100 \mathrm{ml}$ の試料瓶に移した。砂と藻類群落とを分離するため, 試料瓶に $30 \mathrm{ml}$ 程度 の蒸留水を加えて蓋をし，1 分程度よく振って，上澄みを別の試料瓶に移した。この操作 を 3〜4回繰り返して試料を得た。

この方法によって採集された藻類には，epipsammon（砂表生藻類）の他に，epipelon (堆積物表生藻類) が含まれていると考えられる (MOORE, 1977; ROUND and BuKHTIYAROVA, 1996)。従って, 本研究で「砂上の藻類」としているものは, 㹨義の砂表 生藻類ではなく, 砂の堆積した場所に存在していた藻類の全体を指している。

(4)ツルヨシ：水深 $20 \mathrm{~cm}$ 以梁にある, 直径 $4 \mathrm{~mm}$ 以上の匍甸茥を, 直径 $\times$ 長さ $=8 \mathrm{~cm}^{2}$ に なるように切断し，表面の付着物を蒸留水で水洗しながら歯ブラシでこすり落として採 集した。

採集した試料は $1 \%$ 酢酸ルゴールで固定し, 研究室で $10 \mathrm{ml}$ に濃縮して，1\%ホルマ リンを追加して保存した。

\section{計数と同定}

実験室に持ち帰つた群落試料は，まず超音波洗浄機で 10 秒程度洗浄して凝集をほぐし， 試験管攪拌機で覺拌して, 計数用の試料とした。計数は深さ $0.1 \mathrm{~mm}$ の血球測定板を用い て, ×625の光学顕微鏡下で定量的に行った。計数の際には藻類を, (1)珪藻, (2)球状ラン藻, (3)細い糸状ラン藻 (太さ $4 \mu \mathrm{m}$ 以下：主にHomoeothrix, Heteroleibleinia などの丵生種), (4)太い糸状ラン藻 (太さ $4 \mu \mathrm{m}$ 以上), (5)緑藻 (接合藻を含む), (6)その他, の6つの群に分 けた。本研究では細胞数を計数するのではなく，10×10（=121 格子目）の接眼格子を用 い, 直下に藻類のある格子目の数を計数した。この計数方法では各種藻類の細胞の大きさ の違いが加味され，細胞数を計数した場合よりも実質的な優占度を反映したものになる。 原則として藻類のある格子目数が 300 以上になるまで計数したが, 200 格子（=24200 格 子目）を計数しても藻類のある格子目数が 300 に達しなかった場合には，その時点で計数 を打ち切った。

付着藻類群落の量的な評洒は被度指数 (cover index $=\mathrm{CI}:$ OHTSUKA, 1998)によって行つ た。これは付着藻類群落の細胞の投影面積を, その群落が占める付着基質面積で割った値 である。本研究では付着基質面積を，付着基質を上から見たときの投影面積と定義した。 被度指数は現存量を直接表すものではないが, 群落の現存量あるいは立体構造の指標とな る指数である。

珪藻の種組成を知るために，酸処理試料を計数した。各試料の一部を試験管にとり，そ れぞれ熱濃硫酸と硝酸カリウムで処理後, 蒸留水で繰り返し洗浄した。こうして得られた 珪藻殼の試料を，プレウラックスで封入して永久プレパラートを作成した。各試料につい て 400〜500 殸を, $\times 1000$ の光学顕微鏡下で計数した。

光学顕微鏡下での同定が困難な種は, 種群としてまとめて計数した (LoBo et al, 1990)。 幾つかの試料を走査型電子顕微鏡を用いて観察した結果, Achnanthidium japonicum 種群 としたものには, 少なくとも Achnanthidium japonicum (KoBAyasi) KoBAyasi (=Achnanthes japonica Kobayasi) と Achnanthidium convergens (KoBayasi) KoBayasi (= Achnanthes convergens KoBAYASI) が含まれていた事が判明した。同様に, Nitzschia hantzschiana 種群としたものには，少なくともNitzschia hantzschiana RABENHORST と Nitzschia fonticola GRUNow が含まれていた。Staurosira spp.としたものは，群体を形成して㪍環面 しか見えない場合が多かったために同定が困難だったが, 少なくともStaurosira construens var. venter (=Fragilaria construens var. venter EHRENBERG) と Punctastriata 
linearis WILLIAMS and ROUND (かつて Fragilaria pinnata EHRENBERG と混同されていた) を含んでいた（河島・小林 1994）。Cocconeis placentula EHRENBERG, Gomphonema parvulum KÜtzing, Nitzschia palea (KÜtzing) W. Smith, Synedra ulna Ehrenberg などにつ いても複数の変種が含まれていた可能性が高いが，区別せずに計数した。

珪藻各種の相対優占度についても，殼面の面積による重み付けを行つた。出現した珪藻 各種の殸面の写真 $(\times 2000)$ を数枚ずつ撮影し，スキャナーでコンピューターに取り込ん で, NIH Image (RASBAND, National Institute of Health, USA) を用いて面積を求めた。 続いて珪藻各種の款数と面積の積を算出し，その全体に占める割合を相対優占度とした。

なお，ツルヨシ上群落の解析結果の一部は，既に OHTSUKA (1998)で発表されている。

\section{統計処理}

生息場所間での珪藻群落の種組成の違いは，同一生息場所内での種組成の違いと比較し

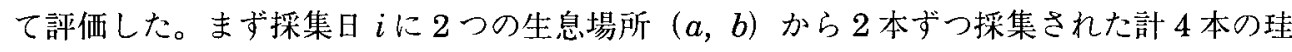
藻群落試料 ( $i a 1, i a 2, i b 1, i b 2)$ )相互間で, 改良松下距離 (modified MATusITA's distance : OHTSUKa 1998)

$$
d(i a 1, i a 2), d(i a 1, i b 1), d(i a 1, i b 2), d(i a 2, i b 1), d(i a 2, i b 2), d(i b 1, i b 2)
$$

を計算した。そして各採集日について，異なる生息場所間の距離の平均值

$$
\frac{1}{4}\{d(i a 1, i b 1)+d(i a 1, i b 2)+d(i a 2, i b 1)+d(i a 2, i b 2)\}
$$

（以降これを「生息場所間の平均群落距離」と呼ぶ）と，同じ生息場所内の距離の平均值

$$
\frac{1}{2}\{d(i a 1, i a 2)+d(i b 1, i b 2)\}
$$

（以降これを「生息場所内の平均群落距離」と呼ぶ）を比較することによって，生息場所間 の違いがあるかどうかを検討した。

珪藻の種組成をもとに，クラスター分析も試みた。集約的方法で分類した。距離尺度に は改良松下距離を用い, クラスターの併合は非加重群平均法 (SNEATH and SOKAL 1973) によって行った。そして, 分類された群落型それぞれについて, 種組成の特徵を把握した。

「生息場所間の比較」は，種組成の違いを，生息場所という外的基準を用いて評価する 方法である。一方，クラス夕一分析は，種組成の類似あるいは相違の構造を，外的基準に よらずに評価する方法である。本研究ではクラスター分析の分類結果が，生息場所間の違 いとどのように対応しているかを検討した。

各種珪藻の生息場所間での分布の違いは,相対優占度の対比較によって検定した(付録)。 生息場所間の相対優占度の比較は，いずれかの生息場所で半数以上の試料に出現した珪藻 について行った。また，生息場所間の被度指数の違いと，藻類全体に占める珪藻の割合に ついても，同様の方法で比較を行った。

結果

\section{被度指数と珪藻の割合の違い}

各生息場所における被度指数の季節変動を Figure 1 に示した。いずれの生息場所でも， 被度指数は6〜7月に小さく, 12〜1月，3４月には大きい傾向を示し，変動パ夕ーンはよ く似ていた。しかし若干の違いも認められた。例えば，8－9月に大礫では現存量の大きな ピークが認められたが，中砅と砂ではピークは小さく、ツルヨシではピークははとんど認 

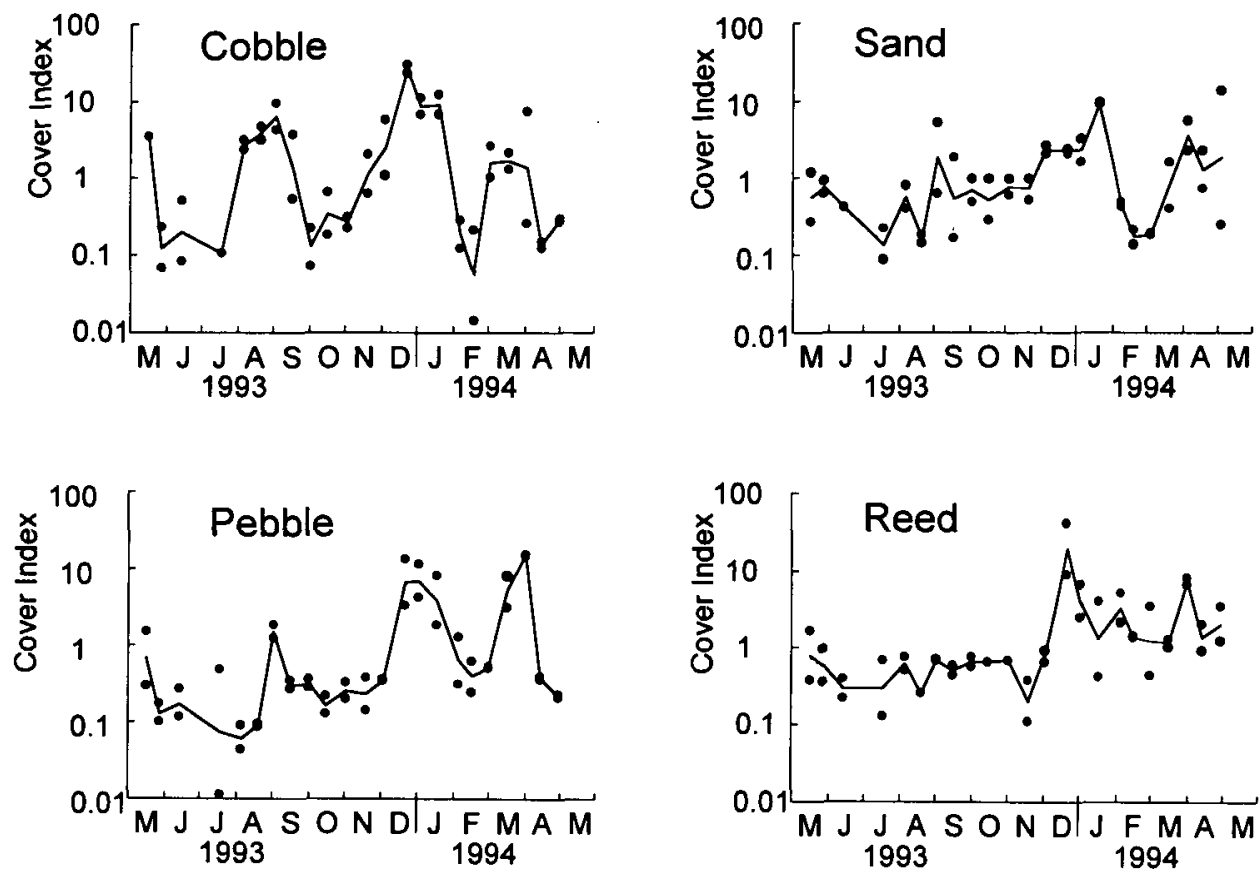

Fig. 1. Seasonal change in cover index (CI) in each habitat. Dots indicate values of samples. Lines indicate geometric means within sampling dates.

められなかった。

被度指数の分布はいずれの生息場所でも值の小さい方に偏っており，対数変換した方が より正規分布に近づいた。そこで平均值および標準偏差は常用対数值（10を底とする）か

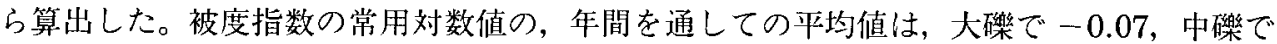
-0.28 , 砂で -0.11 , ツルヨシで 0.00 であった。中礫の被度指数は，ツルヨシ，砂の被度

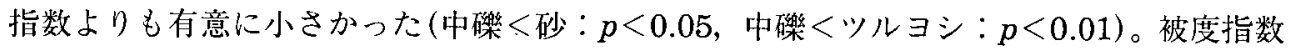
の常用対数值の標準偏差は, 大礫で 0.80 , 中磁で 0.72 , 砂で 0.53 , ッルヨシで 0.52 であっ た。いずれの生息場所でも被度指数は大きく変動したが, 砂やッルヨシの試料では大碟, 中礫の試料よりもやや変動が小さい傾向が見られた。

藻類群落は大部分が珪藻と藍藻から構成されていた。被度指数の全体に珪藻が占める割 合の平均值は, 大硫で 0.62 , 中硆で 0.86 , 砂で 0.96 , ッルヨシで 0.85 であった。大䃇に

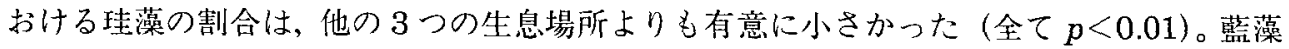
は大部分が Homoeothrix janthina (BoRN. and FLAH.) K. STARMACH などの細い叢生の糸状 藍藻だった。細い糸状藍藻が全藻類量の半分以上に達した試料は, 大砅では 45 試料中に 12 試料あったが，他の生息場所では見られなかった。細い糸状藍藻が半分以上を占めた試料 は, 全て 5 月 から 12 月まで採集された。一方, 砂における珪藻の割合は, 他の 3 つ生 息場所よりも有意に大きかった（全て $p<0.01 ） 。$

\section{珪藻群落の種組成の違い}

全試料から計 155 種 (変種, 品種として扱われているものを含む)の珪藻が認められた。 本研究では光学顕微鏡下での区別が難しい種はまとめて計数したので, 実際にはもっと多 くの種が出現していなと考えられる。 
Table 1. Difference (modified Matusita's distance) in diatom assemblages within / between habitats on respective sampling dates. Data are averages with ranges.

\begin{tabular}{l|cccc}
\hline & Cobble & Pebble & Sand & Reed \\
\hline Cobble & $0.41(0.26-0.65)$ & & & \\
Pebble & $0.48(0.24-0.75)$ & $0.35(0.19-0.51)$ & & \\
Sand & $0.56(0.29-0.81)$ & $0.50(0.31-0.74)$ & $0.39(0.24-0.58)$ & \\
Reed & $0.59(0.28-0.85)$ & $0.45(0.24-0.81)$ & $0.54(0.28-0.91)$ & $0.34(0.19-0.67)$ \\
\hline
\end{tabular}
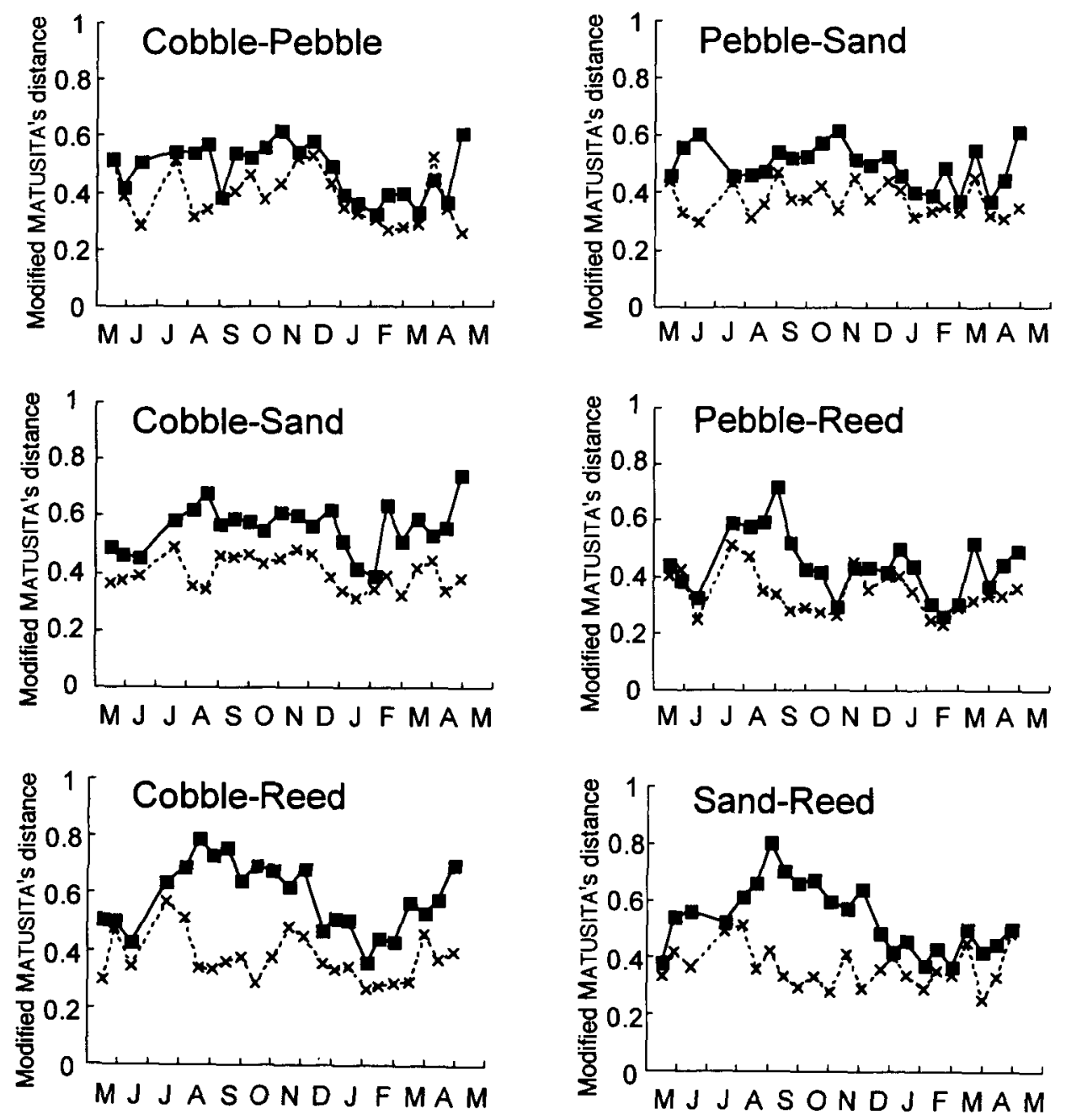

Fig. 2. Comparison of difference between habitats with difference within habitats. - : average of modified MATUSITA's distance between habitats. $-* *-$ : average of modified MATUSITA's distance within habitats.

各生息場所で出現した珪藻の種数（種群を含む）は，大碩で 98 種，中磷で 99 種，砂で 134 種, ツルヨシで 111 種だった。一試料あたりの平均出現種数は, 大砂で 29 種, 中礫で 33 種, 砂で 43 種, ツルヨシで 35 種だった。いずれも，砂で最も種数が多く，大礘で最も 
種数が少なかった。

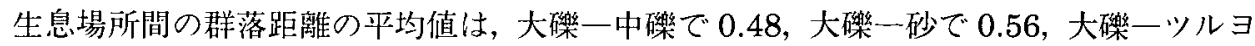

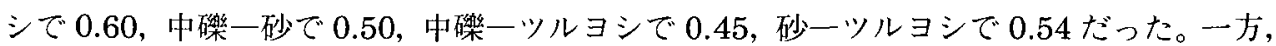

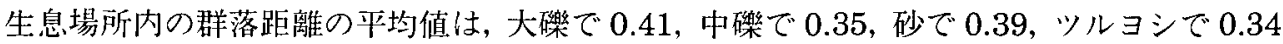
だった (Table 1)。

生息場所間の平均群落距離と, 生息場所内の平均群落距離の季節変動を比較した（Fig. 2)。ほとんどの場合, 生息場所間の平均群落距離は, 生息場所内の平均群落距離よりも大 きかった。全ての生息場所間で, 平均群落距離は 2 3月に最小になった。また, ツルヨシ

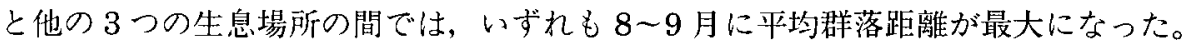

併合距離 0.55 を基準とした場合，群落試料は10の型に分類された (Fig. 3)。それぞれ の群落型の種組成の概要を Table 2 に，各採集日の生息場所ごとの群落型を Table 3 に示 した。Nitzschia dissipata などを優占種とする群落型（群落型Ｉ）は，各生息場所に共通 して見られた。特に 1 月〜 4 月前半の採集日には, 4 つの生息場所の全てから群落型 I の試 料が採集された。他の群落型については，生息場所間で出現パターンに偏りが見られた。

Cocconeis placentula が著しく優占する群落型（群落型II）は 5 月〜1月に各生息場所で見 られたが，中礫とッルヨシに多く，大礫と砂では少なかった。Navicula gregaria, Navicula sp. 1 (Navicula viridula var. linearis Hustedtに似るが，長さ35〜50 $\mu \mathrm{m}$ と小さい) な どを優占種とする群落型（群落型III）は，7月～1月上旬に砂で多く見られ，中砂でも見ら れたが，大礫とツルヨシでは見られなかった。群落型V (Achnanthidium japonicum 種群 が著しく優占)，群落型VI (A. japonicum 種群, C. placentulaなどが優占), 群落型VII (Nitzschia hantzschiana 種群などが優占）の3つの型は大礫だけで見られた。群落型IV (Reimeria sinuata = Cymbella sinuataなどが優占)，群落型VIII（Navicula yuraensis が優 占), 群落型IX (N. gregaria または Navicula pseudoacceptata が優占) の3つの型は, 大 礫抢よび中磁でのみ見られた。群落型X (1 試料のみ：8月後半にツルヨシから採集）は他 の群落型と大きく異なり, Nitzschia acidoclinata と Navicula atomus の 2 種がともに優占 した。

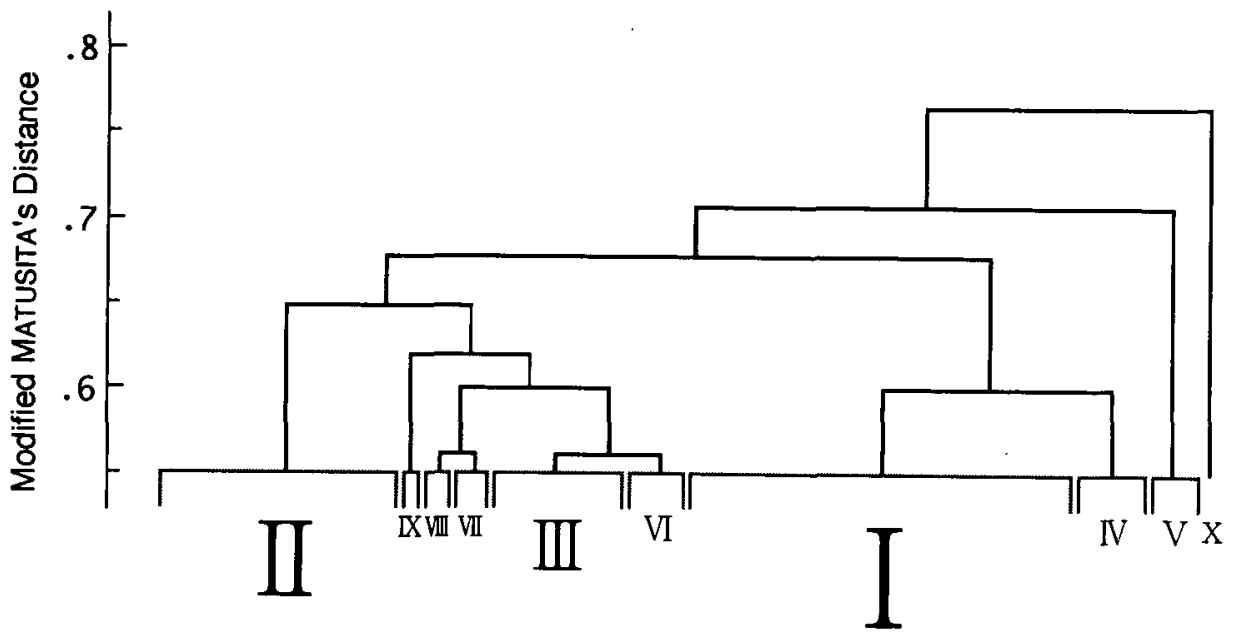

Fig. 3. Summarized dendrogram of cluster analysis using modified MAtusita's distance and UPGAM method. The analysis was performed based on the relative abundance data of diatom species. 
Table 2. Diatom community types classified using cluster analysis. Each value is mean relative abundance (\%) within community type. $[+:$ occurred but less than $0.5 \%$ on average ; - : did not occur.]

\begin{tabular}{|c|c|c|c|c|c|c|c|c|c|c|}
\hline Community Type & I & II & III & IV & $\mathrm{V}$ & VI & VII & VIII & IX & $\mathrm{X}$ \\
\hline Number of Sample & 78 & 46 & 25 & 9 & 7 & 6 & 5 & 4 & 2 & 1 \\
\hline Cocconeis placentula EHRENBERG & 8 & 59 & 11 & 7 & 5 & 14 & 2 & 5 & 4 & 3 \\
\hline $\begin{array}{l}\text { Achnanthidium japonicum } \\
\qquad \text { (KOBAYASI) KOBAYASI* }\end{array}$ & 3 & 4 & 3 & 9 & 53 & 18 & 9 & 3 & 1 & 1 \\
\hline Novicula yuraensis Gотон & 1 & 3 & 7 & + & 3 & 7 & 12 & 35 & 2 & 10 \\
\hline Nitzschia hantzschiana RABENHORST** & 2 & 2 & 2 & 15 & 9 & 2 & 28 & 3 & 4 & 2 \\
\hline Navicula gregaria DoNKIN & 11 & 2 & 13 & 7 & 2 & 6 & 4 & 9 & 27 & 2 \\
\hline Navicula pseudoacceptata KoBAYASI & + & 1 & 4 & 1 & + & 1 & 4 & 4 & 22 & + \\
\hline Nitzschia dissipata (KÜTZING) GRUNOW & 21 & 2 & 4 & 12 & 3 & 6 & 1 & 1 & + & 1 \\
\hline Nitzschia acidoclinata LANGE-BERTALOT & + & + & + & - & + & + & + & - & - & 19 \\
\hline Navicula atomus (KÜTZING) GRUNOW & + & + & + & 5 & 1 & + & 2 & 1 & 9 & 19 \\
\hline $\begin{array}{l}\text { Reimeria sinuata } \\
\text { (GREGORY) KOCIOLEC \& STOERMER }\end{array}$ & 1 & 3 & 2 & 17 & 3 & 1 & 4 & 1 & 3 & + \\
\hline Navicula sp. $1^{* * *}$ & + & + & 12 & - & + & 1 & & + & - & - \\
\hline
\end{tabular}

* Not distinguished from Achnanthidium convergens (KoBayasi) KoBayasi.

** Not distinguished from Nitzschia fonticola GRUNow.

*** Similar to Navicula viridula var. linearis HustedT, but much smaller $(35-50 \mu \mathrm{m}$ in length, 9-10 $\mu \mathrm{m}$ in width).

Table 3. Community types occurring on respective sampling dates. [- : samples not collected]

\begin{tabular}{|c|c|c|c|c|c|c|c|c|c|c|c|c|c|}
\hline Habitat & May & Jun. & Jul. & Aug. & Sep. & Oct. & Nov. & Dec. & Jan. & Feb. & Mar. & Apr. & May \\
\hline Cobble & IV & $\begin{array}{ll}\text { II } & \text { II } \\
\text { I } & \text { I }\end{array}$ & $\begin{array}{l}-I V \\
-\quad I X\end{array}$ & $\begin{array}{l}\text { VII VII } \\
\text { VII VII }\end{array}$ & $\begin{array}{l}\text { VII VII } \\
\text { VII V }\end{array}$ & $\begin{array}{ll}\text { VI VI } \\
\text { V VI }\end{array}$ & $\begin{array}{ll}\mathrm{VI} & \mathrm{VI} \\
\mathrm{V} & \mathrm{V}\end{array}$ & $\begin{array}{cc}\text { V } & \text { I } \\
\text { VI } & \text { I }\end{array}$ & $\begin{array}{ll}\text { I } & \text { I } \\
\text { I } & \text { I }\end{array}$ & $\begin{array}{ll}\text { I } & \text { I } \\
\text { I } & \text { I }\end{array}$ & $\begin{array}{ll}I & I \\
I & I\end{array}$ & $\begin{array}{cc}\text { IV } & \text { IV } \\
\text { I } & \text { IV }\end{array}$ & $\begin{array}{l}\text { V } \\
\text { V }\end{array}$ \\
\hline Pebble & $\begin{array}{l}\text { N } \\
\text { N }\end{array}$ & $\begin{array}{ll}\text { II } & \text { II } \\
\text { II } & \text { II }\end{array}$ & $\begin{array}{l}- \text { IX } \\
\text { - III }\end{array}$ & $\begin{array}{ll}\text { III } & \text { III } \\
\text { III } & \text { II }\end{array}$ & $\begin{array}{ll}\text { VII II } \\
\text { VIII II }\end{array}$ & $\begin{array}{ll}\text { II } & \text { II } \\
\text { II } & \text { II }\end{array}$ & $\begin{array}{ll}\text { II } & \text { II } \\
\text { II } & \text { II }\end{array}$ & $\begin{array}{ll}\text { II } & \text { I } \\
\text { II } & \text { I }\end{array}$ & $\begin{array}{ll}\text { I } & \text { I } \\
\text { I } & I\end{array}$ & $\begin{array}{ll}\text { I } & \text { I } \\
\text { I } & \text { I }\end{array}$ & $\begin{array}{ll}\text { I } & \text { I } \\
\text { I } & I\end{array}$ & $\begin{array}{ll}\text { I } & \text { IV } \\
\text { I } & \text { IV }\end{array}$ & $\begin{array}{l}\text { II } \\
\text { II }\end{array}$ \\
\hline Sand & $\begin{array}{l}\text { I } \\
\text { I }\end{array}$ & $\begin{array}{ll}I & I \\
I & I\end{array}$ & $\begin{array}{l}- \\
- \\
-\end{array}$ & $\begin{array}{ll}\text { III } & \text { II } \\
\text { III II }\end{array}$ & $\begin{array}{l}\text { III III } \\
\text { III III }\end{array}$ & $\begin{array}{ll}\text { III } & \text { II } \\
\text { III } & \text { III }\end{array}$ & $\begin{array}{ll}\text { III } & \text { III } \\
\text { III I II }\end{array}$ & $\begin{array}{ll}\text { III III } \\
\text { III III }\end{array}$ & $\begin{array}{cc}\text { I } & \text { I } \\
\text { III } & \text { I }\end{array}$ & $\begin{array}{ll}\text { I } & \text { I } \\
\text { I } & \text { I }\end{array}$ & $\begin{array}{ll}\text { I } & \text { I } \\
\text { I } & \text { I }\end{array}$ & $\begin{array}{ll}\text { I } & \text { I } \\
\text { I } & \text { I }\end{array}$ & $\begin{array}{l}\text { I } \\
\text { I }\end{array}$ \\
\hline Reed & I & $\begin{array}{ll}\text { I } & \text { II } \\
\text { II } & \text { II }\end{array}$ & $\begin{array}{ll}- & \text { II } \\
- & \text { II }\end{array}$ & $\begin{array}{cl}\mathrm{X} & \text { II } \\
\text { II } & \text { II }\end{array}$ & $\begin{array}{ll}\text { II } & \text { II } \\
\text { II } & \text { II }\end{array}$ & $\begin{array}{ll}\text { II } & \text { II } \\
\text { II } & \text { II }\end{array}$ & $\begin{array}{ll}\text { II } & \text { II } \\
\text { II } & \text { II }\end{array}$ & $\begin{array}{ll}\text { II } & \text { I } \\
\text { II } & \text { I }\end{array}$ & $\begin{array}{ll}\text { II } & \text { II } \\
\text { I } & \text { I }\end{array}$ & $\begin{array}{ll}\text { I } & \text { I } \\
\text { I } & \text { I }\end{array}$ & $\begin{array}{ll}\text { I } & \text { I } \\
\text { I } & I\end{array}$ & $\begin{array}{ll}\text { I } & \text { I } \\
\text { I } & \text { I }\end{array}$ & $\begin{array}{l}\text { I } \\
\text { I }\end{array}$ \\
\hline
\end{tabular}

\section{珪藻各種の優占度の違い}

いずれかの生息場所で半数以上の試料に出現した珪藻は計 40 種（種群を含む）だった。 各種珘藻の相対優占度の, 生息場所間での比較結果を Table 4 に示した。特定の生息場所だ けに出現するような種はなかったが，多くの種で生息場所間の優占度の違いが見られた。 ある生息場所で多い種を, 有意水準 $5 \%$ で他の全ての生息場所よりも多いものと定義した 場合，以下のようになった。

大礫で多かった種：A. japonicum 種群, Fragilaria capitellata, Nitzschia paleacea. 
Table 4. Differences in abundance of each diatom species among habitats. Values are mean relative abundances (\%) within habitats. Results of testing significance of difference are : $++=$ more abundant in former habitat (if C-P, C) with $0.5 \%$ significance level, $+=$ more abundant in former habitat with $5 \%$ significance level, $-=$ more abundant in latter habitat (if C-P, P) with $5 \%$ significance level, $--=$ more abundant in latter habitat with $0.5 \%$ significance level. [C : cobble; P ; pebble ; S : sand ; R : reed (stolon of Phragmites)].

\begin{tabular}{|c|c|c|c|c|c|c|c|c|c|c|}
\hline \multirow[t]{2}{*}{ Species } & \multicolumn{4}{|c|}{ Mean Relative Abundance } & \multicolumn{6}{|c|}{ Significance of difference } \\
\hline & $\mathrm{c}$ & $\mathbf{P}$ & $\mathbf{S}$ & R & C-P & $\mathrm{C}-\mathrm{S}$ & $\mathrm{C}-\mathrm{R}$ & P-S & P-R & S-R \\
\hline Achnanthidium minutissimum (KÜTZING) CZARNECKI & 0.5 & 0.4 & 0.3 & 0.3 & & & + & & & + \\
\hline A. japonicum (KoBayasI) KOBAYASI ${ }^{\dagger}$ & 14.6 & 4.3 & 3.1 & 1.8 & ++ & ++ & ++ & & ++ & ++ \\
\hline A. lanceolatum BRÉBISSON & 0.8 & 2.6 & 2.0 & 2.4 & -- & - & -- & & & \\
\hline Achnanthes subhudsonis HUSTEDT & 0.7 & 0.4 & 0.8 & 0.3 & & -- & & + & & ++ \\
\hline Amphora pediculus (KüTZING) GRUNOW & 0.5 & 1.0 & 0.6 & 0.2 & -- & -- & & & ++ & ++ \\
\hline Cocconeis pediculus EHRENBERG & 0.8 & 0.4 & 0.7 & 0.9 & & - & & - & -- & \\
\hline C. placentula EHRENBERG & 7.0 & 23.2 & 10.1 & 43.0 & - & -- & - & & -- & -- \\
\hline Cymbella turgidula var. nipponica SKvORTzOW & 3.1 & 1.6 & 1.0 & 0.5 & + & & ++ & & + & + \\
\hline Diatoma vulgare BORY & 1.2 & 1.5 & 1.1 & 1.9 & & & & & & \\
\hline Encyonema minutum (HILSE) MANN & 2.4 & 2.5 & 3.6 & 4.6 & & & & - & -- & \\
\hline Fragilaria capitellata (GRUNOW) J. B. Petersen & 2.9 & 1.4 & 0.9 & 1.0 & ++ & ++ & ++ & & & \\
\hline F. vaucheriae (KützIng) J. B. Petersen & 0.2 & 0.2 & 0.3 & 0.3 & & -- & & -- & - & \\
\hline Geissleria decussis (ØSTRUP) LANGe-BERTALOt \& METZELTIN & 0.2 & 1.2 & 1.3 & 0.2 & -- & -- & & - & ++ & ++ \\
\hline Gomphonema parvulum KUTZING & 0.6 & 0.7 & 0.7 & 1.1 & & & -- & - & -- & - \\
\hline Gomphoneis quadripunctata (ØSTRUP) P. DAwSON & 3.3 & 3.7 & 1.3 & 1.8 & & & & & & + \\
\hline Melosira varians AGARDH & 1.3 & 1.2 & 2.6 & 3.3 & & -- & -- & -- & -- & \\
\hline Navicula atomus GRUNOW & 1.6 & 0.7 & 0.1 & 0.6 & & ++ & ++ & ++ & ++ & \\
\hline N. capitatoradiata GERMAIN & 0.2 & 0.2 & 0.5 & 0.1 & & & & - & & ++ \\
\hline N. cryptocephala KÜTZING & 0.2 & 0.2 & 0.5 & 0.3 & & - & & - & & + \\
\hline N. cryptotenella LANGE-BERTALOT & 1.9 & 1.2 & 1.8 & 1.4 & & & & - & - & + \\
\hline N. gregaria DONKIN & 5.3 & 7.8 & 15.3 & 4.3 & - & - & & -- & ++ & ++ \\
\hline N. minima GRUNOW & 1.1 & 0.5 & 0.3 & 0.1 & & & + & & + & ++ \\
\hline N. nipponica (SKVORTZOW) LANGE-BERTALOT & 0.6 & 0.6 & 1.1 & 1.0 & & & & - & - & \\
\hline$N$ pseudoacceptata KOBAYASI & 1.6 & 2.3 & 2.3 & 0.3 & -- & -- & + & -- & ++ & ++ \\
\hline N. yuraensis GOTOH & 4.7 & 4.8 & 3.2 & 2.1 & & & & & $+t$ & ++ \\
\hline Navicula sp. $1^{\dagger}$ & 0.2 & 0.3 & 6.9 & 0.1 & & -- & & - & + & ++ \\
\hline Navicula sp. $2^{\# 1}$ & 0.3 & 0.3 & 1.5 & 0.2 & & - & & - & + & ++ \\
\hline Navicula sp. $3^{* 2}$ & 0.4 & 0.2 & 0.1 & 0.1 & & + & & & & \\
\hline Nitzschia dissipata (KüTZING) GRUNOW & 14.6 & 10.0 & 11.4 & 8.6 & + & & ++ & -- & & ++ \\
\hline N. linearis (AGARDH) W. SMITH & 0.3 & 0.7 & 1.6 & 1.5 & - & - & -- & - & - & \\
\hline$N$. palea (KUTZING) W. SMITH & 0.8 & 1.0 & 1.4 & 0.6 & & -- & & -- & & ++ \\
\hline N. paleacea GRUNOW & 0.9 & 0.3 & 0.3 & 0.2 & + & + & ++ & & + & + \\
\hline N. recta HANTZSCH & 0.2 & 0.3 & 0.5 & 0.1 & & -- & & - & & ++ \\
\hline N. hantzschiana 'RABENHORST ${ }^{\dagger}$ & 7.9 & 3.5 & 2.0 & 1.2 & & + & ++ & + & ++ & ++ \\
\hline Reimeria sinuata (GREGORY) KOCIOLEC \& STOERMER & 3.7 & 3.8 & 1.0 & 0.8 & - & & ++ & ++ & ++ & + \\
\hline Rhoicosphenia abbreviata (AGARDH) LANGE-BERTALOT & 2.2 & 3.4 & 2.9 & 1.4 & -- & - & & & ++ & ++ \\
\hline Staurosira spp. ${ }^{* 3}$ & 0.1 & 0.1 & 0.6 & 0.3 & & -- & -- & -- & & \\
\hline Surirella angusta KUTZING & 0.2 & 0.1 & 0.4 & $\cdot 0.2$ & & & & - & - & \\
\hline Synedra inaequalis KOBAYASI & 3.7 & 3.2 & 1.7 & 1.5 & + & & ++ & & ++ & $+t$ \\
\hline S. ulna EHRENBERG & 3.6 & 4.3 & 4.3 & 5.6 & & & & & & \\
\hline
\end{tabular}

$\dagger$ : see Table 2.

${ }^{*} 1$ : Similar to Navicula exilis KüTZING, but striae are alternately longer and shorter about the central area.

*2 : Similar to Navicula cryptotenella LANGE-BERTALOT, but shorter (13-17 $\mu \mathrm{m})$, more rhombic, and with finer striae $\left(18^{-20}\right.$ striae $\left./ 10 \mu \mathrm{m}\right)$.

*3: Mainly Staurosira construens var. venter (EHRENBERG), but some similar species such as Punctastriata linearis WILliams \& Round are not distinguished. 
小礫で多かった種：R. sinuata.

砂で多かった種: Achnanthes subhudsonis, Geissleria decussis (= Navicula decussis), Navicula cryptocephala, N. gregaria, N. pseudoacceptata, Navicula sp. 1, Navicula sp. 2 (Navicula exilis KüTZING に似るが，中心区の近くの条線が交互に長短する)，Nitzschia palea, Nitzschia recta.

ツルヨシで多かった種：C. placentula, Gomphonema parvulum.

一方, Synedra ulna, Diatoma vulgareの 2 種については，全ての生息場所間で相对優 占度に有意差が見られなかった。

\section{考察}

\section{生息場所間の群落距離}

賀茂川中流域では, 生息場所（大礫・中礫・砂・ツルヨシ）間の群落距離は, 生息場所 内の群落距離よりも明らかに大きい傾向が見られた。従って群落は生息場所ごとに異なっ ていたと結論できる。これは DOUGLAS (1958)，KATOH（1991b）の結論と一致する。

冬期には生息場所間の群落距離が小さくなり, クラスター分析では各生息場所とも 1 つ の群落型（群落型 I）にまとまった。にもかかわらず，生息場所間の群落距離が生息場所 内の群落距離よりも大きい傾向は維持されていた。例えば, 1 月〜 3 月の大礫一中礫間の群 落距離は, 平均で 0.37 とさかったが, 生息場所内の群落距離よりも大きい傾向は維持さ れていた。この值を他の研究と比較するために, SIMI (久野, 1968 ; STANDER, 1970) と Bray-CuRTIS の類似度指数（BRAY and CuRTIS，1957）を算出したところ，それぞれ 0.86, 0.67 となっ。この值はそれぞれ，O’Quinn and Sullivan (1983), KatoH（1991a）が, 生息場所間の差がほとんどないと結論した際の值とほぼ同じである。従って，生息場所間 の違いを論じる際には，同一生息場所内で反復採集しな試料間の違いの大きさと比較する 必要があると考える (EMINson and Moss, 1980 ; Millie and Lowe, 1983)。

但し, 本研究も含む大部分の研究では, 珪藻の酸処理標本を計数しているため, 群落の 種組成が死㪍の混入によって正確に把握されていない恐れがある。細胞核染色法（後藤、 1988a，b）などによって生きた細胞だけを計数した場合に，本研究と同様の結果になるか どうかについては, 今後の課題であろう。

\section{付着基質の性質による違い}

砂の群落で他の生息場所よりも相対優占度が大きかった種は，統計的検定の対象とした 40 種のうち 9 種に及んだ。そのうち 7 種が Naviculaまたは Nitzschia に属し，これに Geissleria decussis を含めた 8 種が強い運動性を持つと思われる(HARPER, 1977)。しかし, 強い運動性は, 砂表生珪藻よりはむしろ堆積物表生珪藻の特徽であるとされてきた (Round, 1981 ; Round et al., 1990)。また河川では, 砂表面に強固に付着した珪藻だけを 調べた場合（KREJCI and Lowe, 1987 ; Round and BukhTIYAROVA, 1996) だけでなく, 堆 積物表生珪藻を砂表生珪藻から分離しなかった場合 (MOORE, 1977 ; MILLER et al., 1987; STEVENSON and HASHIM, 1989）でも，基質密着型で運動性の弱い小型種が優占したという 報告が多い。

賀茂川中流域の河床は主に磁で構成されており，粒径が相对的に小さい砂は蛇行部にで きた洲の周辺などに堆積していた。また, 採集した砂にはシルトや落葉の破片なども混じっ ていた。従って，砂を採集した場所は，粒径の小さい砂・シルトやデトリタスが日常的に 沈積する環境だったことが推察される。このような環境では，付着珪藻は堆積物によって 
埋められる危険性が大きい。運動性をもつ種は埋もれても自力で表層へ脱出できたために, 相対的に多くなったと考之られる (DARLEY, 1982；ROUND et al., 1990)。

砂で多かった種のうち, Achnanthes subhudsonisについては, 基質密着型で運動性の低 い小型種という，一般的な秒表生珪藻の特徴に一致している。しかし同様の特徵をもつと 思われる Achnanthidium属の種は, 砂で多い傾向を示さなかった。その理由として, 次の 2つが考えられる。1，堆積の卓越した環境であった事が, 運動性の弱いAchnanthidium 属 の増殖を困難にした。2. 砂の攪抖・洗浄という採集法をとったために, 歯ブラシによる擦 り落としを行った他の基質に比べて, 基質表面に強固に密着した Achnanthidium 属の採集 効率が悪かった。

ツルヨシ上では，夏期から秋期にかけて Cocconeis placentula が著しく優占した。被子 植物上で夏期または秋期に C. placentula が優占したとする報告は，他にも多数見られる (Tuchman and Blinn, 1979; Hickman, 1982; Blindow, 1987; Goldsborough and HICKMAN, 1991)。本研究において, C. placentulaは他の生息場所でも被度指数の小さいと きにしばしば優占したが，夏期〜秋期にツルヨシ上で最も高い相対優占度を示した。従っ てッルヨシが, C. placentulaにとって相対的に有利な何らかの環境条件を提供したことが 推察される。その一つとして, C. placentulaのような基質密着型の珪藻が, 立体的な群落 をつくる藻類よりもツルヨシからのリンの供給（BURKHOLDER and WETZEL, 1990）を受け やすかった可能性が指摘できる。しかし一方で, 単にッルヨシの表面形状などが $C$. placentulaの付着に有利であったという可能性もある (Goldsborough and HickMaN, 1991)。

Synedra ulna と Diatoma vulgare については, 生息場所間の相対優占度の違いが見られ なかった。この 2 種については群落の上層部を占める傾向がある(OHTSUKA, 1998) ので, 付着基質の影響を受けにくかった可能性がある。

\section{付着基質以外の要因による違い}

珪藻群落には，付着基質の性質以外にも様々な要因が影響したと考えられる。以下，流 速の違いと, 㗂の転がり易さの違いが, 珪藻群落の種組成と現存量に及ぼした影響につい て考察する。

A. 流速の違い：予備研究段階の 1992 年 8 月と調査期間の 1994 年 5 月に, 各生息場所 について計 6 回ずつ, 付着基質の上 $5 \mathrm{~cm}$ の流速を测定した。その結果，平均流速は大磼で

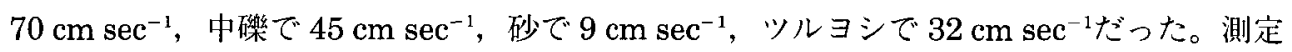
值のばらつきは大きかったものの, 流速はほぼ大磂〉中礫ミッルヨシ>砂の順だったと言 える。中磔上の珪藻群落は他の 3 つの生息場所の群落との類似性が高く, 特にツルヨシと の群落類似度が高かった。この原因の一つとして，中磁上の流速が中間的であり，特にツ ルヨシ上に近い流速だったことが考えられる。

流速が大きい場合，基質密着型の小型種が相対的に増加するとされている（STEVENSON, 1996)。本研究で大砂に多かった 3 種のうち, Achnanthidium japonicum 種群 $(A$. japonicum および Achnanthidium convergens）は基質密着型の小型種に該当する。しかし A. japonicum は流速の遅い場所を好むという報告もあり（田中・渡辺，1990）, むしろ後に 述べる糸状丵生ラン藻 Homoeothrix janthinaの環境形成作用によって増加したものと思 われる。流速が大きい場所で柄を持つ種が増加するという報告もある（WENDKER，1992； BIGGS and HICKEY, 1994)が, 本研究ではそのような傾向は見られなかった。なお WENDKER (1992)は Synedra rumpens は流速が大きいほど相対的に増加したとしているが，この種 は本研究で大碟に多かった Fragilaria capitellata と形態的によく似ている。 
鎖状の長い群落を形成する種は流れの影響を受けやすく，流速の大きい場所では不利に なると考えられる。鎖状群体を形成する種のうち, Melosira varians, Fragilaria vaucheriae, Staurosira spp.では, 流速の小さい生息場所ほど增加する傾向が見られた。M. varians は夏期に大きな河川の縁の水の淀んだようなところで多く出現するとされている（小林 1995)。またSABATER and RocA（1990）は，F. vaucheriaeが流れの緩い軟水の涌泉で多 く出現したことを報告している。しかし一方で, 同様に鎖状群体を形成する D. vulgareに ついては，今回の観察では生息場所による相対優占度の差が見られなかった。

運動性の強い種が砂で相対的に多くなった事も，流速が小さかったことと関係している 可能性がある。運動性の強い種は一般に付着力が弱い（HARPER, 1977）ために, 流速の大 きい場所では流されやすいと考えられる。

B. 碰の転がり易さの違い：HJULSTRÖM（1935）は, 粒径 $0.5 \mathrm{~mm}$ 以上の砂礫では, 粒徍 が大きいほど限界流速（底面の堆積物が動き出す流速）が大きいことを示した。従って中 磢は大礫よりも小規模な出水で転がって移動したことが推察される。中礫の被度指数が大 磁よりも小さい傾向が見られたのは，出水の際に転がり易かったことに関係しているかも しれない。

磷の転がり易さは, 珪藻の種組成にも影響を及ぼしたと考えられる。ROBINSON and RUSH FORTH（1987）は，河川に人工基質を静置した場合と，一定の期間を置いて裹返した場合の 珪藻の種組成を比較した。そして, 裹返す頻度が高かった場合には, Cocconeis spp., Achnanthes spp.などの基質に水平に付着する種が多くなったことを示した。本研究で $C$. placentula が大礫よりも中磎に多かったのも，同様の現象と解釈することができる。

中礫が転がり易いことが，糸状藻の減少などを介して珪藻群落に間接的な影響を及ぼし た可能性もある (GRIMM and FISHER, 1989)。大礫ではしばしば細い叢生糸状ラン藻（主に Homoeothrix janthina)の著しい優占が見られたが, 中礫では細い系状ラン藻の占める割合 は常に半分以下であった。H. janthina は遷移過程の後期に侵入し（田中・渡辺，1990）, 大部分の珪藻よりも長く伸びるので，碩が転がることが増殖に不利に働くと考えられる。 大磁で細い系状ラン藻が全藻類量の半分以上に達した 12 試料のうち，4 試料で $A$. japonicum 種群が, 他の 4 試料ではNitzschia hantzschiana 種群が珪藻の優占種になっ た。この 2 種群はいずれも中礫では優占種にならなかった。また大礫上でも，N. hantzschiana 種群が珪藻の第一優占種になったのは, 細い系状ラン藻が著しく優占した場合に限 られていた。A. japonicum が H. janthinaに随伴したとする報告は他にも見られる(後藤・ 根来, 1986 ; 渡辺ほか, 1986)。N. hantzschiana 種群とよく似た Nitzschia frustulum var. perpusillaが H. janthina に随伴したとする報告もある（渡辺ほか，1986）。

田中・渡辺（1990）は, H. janthina が増加すると, その基部周辺に小型で遅い流れを好 む A. japonicumに有利な環境が形成されると考察している。N. hantzschiana 種群も小型 で, 他の Nitzschia 属と同様に付着力があまり強くないと推察される(HARPER, 1977)ので, 同様にH. janthinaの基部が好適な生息場所になったと考えられる。一方, OHTSUKA (1998) は, 本研究と同じ調查地点のツルヨシ匍匐荎上に発達した, 丵生系状ラン藻 Heteroleibleinia sp.の系状体中に, Nitzschia sp. (N. hantzschiana と思われる) が混在していたの を観察している。従って, N. hantzschiana 種群は, H. janthinaの基部だけではなく, 系 状体の上をも生活の場としていた可能性がある。

\section{謝辞}

珪藻試料の同定を行った際に，東京珪藻研究所の故小林弘博士，ならびに東京学芸大学 
の真山茂樹助教授には，多数の有益なご教示を頂いた。また，私の指導教官である京都大 学の中原紘之教授には，研究方法のご指導を頂くとともに，本稿にたいする貴重なご提言 を多数頂いた。ここに感謝致します。

\section{文献}

Bigcs, B. J. F. and C. W. Hickey (1994) : Periphyton responses to a hydraulic gradient in a regulated river in New Zealand. Freshwater Biol., $32: 49-59$.

Buindow, I. (1987) : The composition and density of epiphyton on several species of submerged macrophytes -The neutral substrate hypothesis tested. Aquat. Bot., $29: 157-168$.

BRAY, J. R. and J. T. CURTIS (1957) : An ordination of the upland forest communities of southern Wisconsin. Ecol. Monogr., $27: 325-349$.

BURKHOLDER, J. M. and R. G. WETzEL (1990) : Epiphytic alkaline phosphatase on natural and artificial plants in an oligotrophic lake: Re-evaluation of the role of macrophytes as a phosphorus source for epiphytes. Limnol. Oceanogr., 35: 736-747.

Darley, W. M. (1982) : Algal Biology: a physiological approach, Blackwell Science Publications, Oxford.

Douglas, B. (1958) : The ecology of the attached diatoms and other algae in a small stony stream. J. Ecol., $46: 295-322$.

Eminson, D. and B. Moss (1980) : The comparison and ecology of periphyton communities in freshwaters. 1. The Influence of host type and external enviroment on community composition. Br. Phycol. J., $15:$ 429-446.

Goldsborough, L. G. and M. Hickman (1991) : A comparison of periphytic algal biomass and community structure on Scirpus validus and on a morphologically similar artificial substratum. J. Phycol., 27 : 196-206.

後藤敏一 (1988a)：珪藻試料の死細胞含有率. 日本水処理生物学会誌, $24: 132-134$.

後藤敏一 (1988b)：細胞核染色法に上る珪藻群落の解析. 珪藻学会誌, 4:67-72.

後藤敏一・根来健一郎 (1986)：清澄な河川，宇川（京都府）の珪藻植生. 陸水雑., 47:77-86.

Grimm, N. B. and S. G. Fisher (1989) : Stability of periphyton and macroinvertebrates to disturbance by flash floods in a desert stream. J. North Am. Benthol. Soc., 8: 293-307. (indirectly cited)

Harper, M. A. (1977) : Movement. In The Biology of Diatoms, D. Werner (ed.) : 224-249. Blackwell Science Publications, Oxford.

HickMAN, M. (1982) : The removal of a heated water discharge from a lake and the effect upon an epiphytic algal community. Hydrobiol., $87: 21-32$.

HJULSTRÖM, F. (1935) : Studies of morphological activity of rivers as illustrated by the River Fyris, Upsala Mineral. Geologis. Inst. Bull., $25: 222-527$. (indirectly cited)

伊東良子（1959）：川底の石の底面における藻類着生状態のちがいについて. 奈良女子大学生物学 会誌, $9: 47-48$.

上條裕規・渡辺仁治 (1975) : 石川県犀川の污水生物学的研究, 特に川底の石の上面下面の水質污 濁階級の相違について。陸水雑., $36: 16-22$.

可児藤吉 (1944)：溪流棲昆虫の生態一カゲロフ・トビケラ・カハゲラその他の昆虫に就いて，日本 生物誌 昆虫上巻, 古川晴男編：171-317, 研究社.

КАтон, K. (1991a) : Variation in species composition of diatom assemblages in an unpolluted river. Jpn. J. Limnol., 52 : 145-151.

КАтон, К. (1991b) : Spatial and seasonal variation of diatom assemblage composition in a partly 
polluted river. Jpn. J. Limnol., $52: 229-239$.

河島綾子・小林 弘 (1994)：阿寒湖の珪藻 (2. 羽状類一広義の Fragilaria). 自然環境科学㗏究, $7: 9-22$.

小林 弘（1995）：羽状目。環境微生物図鑑，小島貞男・須藤隆一・千原光雄編：236-298, 講談 社.

KREJCI, M. E. and R. L. Lowe (1987) : Spatial and temporal variation of epipsammic diatoms in a spring-fed brook. J. Phycol., $23: 585-590$.

久野英二 (1968)：水田における稲ウンカ・ヨコバイ類個体群の動態に関する研究。 九州農業試験 場巢報., $14:$ 131-246.

Lobo, E. A., S. Kitazawa and H. Kobayasi (1990) : The use of scanning electron microscopy as a necessary complement of light microscopy diatom examination for ecological studies. Diatom, $5: 33-43$.

Luttenton, M. R. and R. G. RADA (1986) : Effects of disturbance on epiphytic community architecture. J. Phycol., $22: 320-326$.

Mlller, A. R., R. L. Lowe and J. T. Rotenberry (1987) : Succession of diatom communities on sand grains. J. Ecol, $75: 693-709$.

MilLIe, D. F. and R. L. Lowe (1983) : Studies on Lake Erie's littoral algae; Host specificity and temporal periodicity of epiphytic diatoms. Hydrobiol., $99: 7-18$.

Moore, J. W. (1977) : Seasonal succession of algae in a eutrophic stream in southern England. Hydrobiol., 53 : 181-192.

Oнтsuka, Т. (1998) : Diatom community structure and its seasonal change on stolon of Phragmites japonica. In Proceedings of the Fourteenth International Diatom Symposium, S. Mayama et al. (Eds.), Koeltz Science Book, Königstein. (in printing).

O'Quins, R. and M. J. Sullivan (1983): Community structure dynamics of epilithic and epiphytic diatoms in a Mississippi stream. J. Phycol., $19: 123-128$.

Robinson, C. T. and S. R. Rushrorth (1987) : Effects of physical disturbance and canopy cover on a attached diatom community structure in an Idaho stream. Hydrobiol., 154: 49-59.

Round, F. E. (1981): The Ecology of Algae, Cambridge University Press, Cambridge.

Round, F. E. and L. Bukntuyarova (1996): Epipsammic diatoms -Communities of British rivers. Diatom Res. $11: 363-372$.

Round, F. E., R. M. CRawford and D. G. ManN (1990) : The Diatoms : biology \& morphology of the genera, Cambridge University Press, Cambridge.

SAbater, S. and J. R. Roca (1990) : Some factor affecting distribution of diatom assemblages in Pyrenean springs. Freshwater Biol., 24 : 493-508.

SNeath, P. H. A. and R. R. Sokal (1973) : Numerical taxonomy, W. H. Freeman, San Francisco.

Stander, J. M. (1970) : Diversity and similarity of benthic fauna off Oregon. M. S. Thesis. Oregon State Univ., Corvallis, Oregon. (indirectly cited)

Stevenson, R. J. (1996) : Stimulation and drag of current. In Algal Ecology : freshwater benthic ecosystem, R. J. Stevenson, M. L. Bothwell and R. L. Lowe (eds.), Academic Press, U.S. A.

Stevenson, R. J. and S. HAshim (1989) : Variation in diatom community structure among habitats in sandy stream. J. Phycol., $25: 678-686$.

田中志穂子・渡辺仁治 (1990)：日本の清浄河川における代表的付着澡類群集 Homoeothrix janthina-Achnanthes japonica 群集の形成過程. 藻類., $38:$ 167-177.

Tuchman, M. L. and D. W. BrinN (1979) : Comparison of attached algal communities on natural and artificial substrata along a thermal gradient. Br. Phycol. J., $14: 243^{-254 .}$ 
Tuchman, M. L. and R. J. Stevenson (1980) : Comparison of clay tile, sterilized rock, and natural substrate diatom communities in a small stream in southeastern Michigan, USA. Hydrobiol., $75: 73-79$.

渡辺仁治・鈴-木紀子（1989）：被付着物の違いが付着性珪藻群集の形成と生物学的水質判定に及ほ す影響。陸水雑., $50: 129-137$.

渡辺仁治・田中志穂子・肥塚利江（1986）：紀ノ川の污染地図一付着珪藻群集に基づく有機污濁指 数（DAIpo）を用いて一. 珪藻学会誌, $2: 117-124$.

WENDKER, S. (1992) : Influence of current velocity on diatoms of a small softwater stream. Diatom Res., $7: 387-396$.

大塚泰介：干 606-8224 京都市左京区北白川追分町, 京都大学農学部 (Taisuke OнтsuкA, Faculty of Agriculture, Kyoto University, Kitashirakawa-Oiwake-cho, Sakyo-ku, Kyoto, 606-8224)

(受付：1997年 10 月 9 日；受理：1998年 2 月 24 日)

\title{
Variations in Diatom Community Structure among Habitats within a Morphological Unit in a River
}

\author{
Taisuke OHTSUKA
}

\begin{abstract}
Differences in the species composition of a benthic diatom community among habitats were studied in a fourth order stream in Central Japan. Samples were collected from four different habitats (cobbles, pebbles, sands, and stolons of reed Phragmites japonica) within a morphological unit twice a month from May 1993 to May 1994. In each habitat, especially on cobbles, the temporal variation in an algal standing crop was large. The standing crop on pebbles was significantly smaller than that on sands and reeds. Among habitats, the diatom species composition was different: the differences among habitats were almost always larger than those within a single habitat. The species compositions on cobbles, on sands and on reeds were clearly distinct, but that on pebbles, was somehow similar to the others. Motile diatoms such as Navicula spp. were abundant on sands. In summer and autumn, Cocconeis placentula was dominant on reeds. When rosetteforming filamentous cyanobacteria, mainly Homoeothrix janthina, were dominant on cobbles, Achnanthidium japonicum and Nitzschia hantzschiana often became dominant among diatoms.
\end{abstract}


付

録

付着珪藻の個々の種に注目した場合，相対優占度はしばしば0の値をとり，また季節的 な変動も見られる。そこで, 本研究のデータの構造に適した, 新しいノンパラメトリック な方法を考案して用いた。方法を以下に示す（Table A)。

Table A. Method for testing significance of difference between habitats. In this case, the difference of Achnanthes subhudsonis in relative abundances between pebbles and sands is tested. It is concluded that $A$. subhudsonis is more abundant on sands than pebbles with $0.01 \%$ significance level. [D : number of sample sets ; $\mathrm{E}\left(r_{i a 1}+r_{i a 2}\right)$ : expected value of $\left(r_{i a 1}+r_{i a 2}\right)$ assuming the ranks are random; $\mathrm{V}\left(r_{i a 1}+r_{i a 2}\right)$ : variance of $\left(r_{i a 1}+r_{i a 2}\right)$ assuming the ranks are random.].

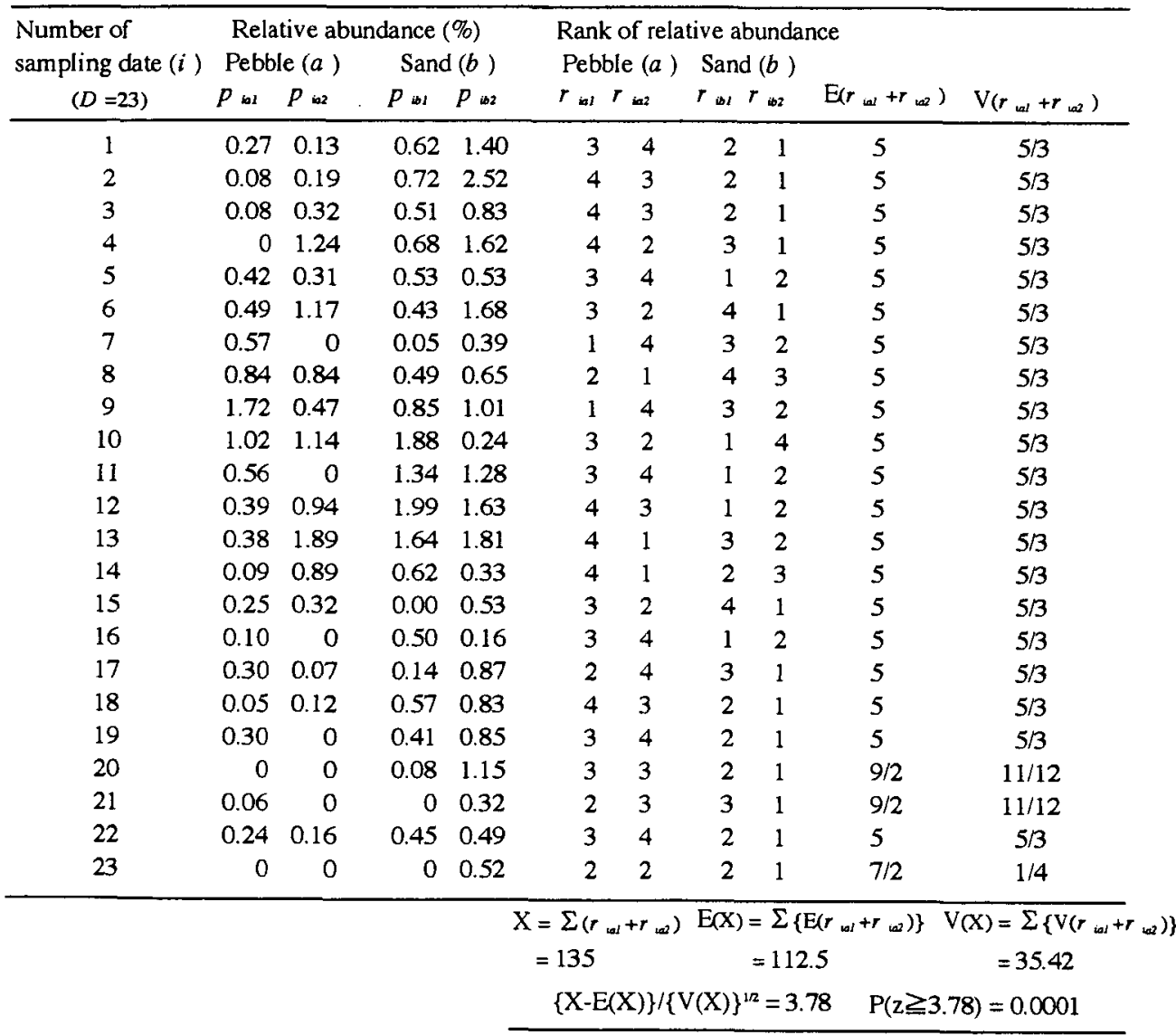

(a) まず，採集日 $i$ につの生息場所 $(a, b)$ から採集された計 4 本の試料 ( $i a 1, i a 2, i b 1$, $i b 2)$ における，注目した珪藻の相対頻度（ $\left.p_{i a 1}, p_{i a 2}, p_{i b 1}, p_{i b 2}\right)$ に大きい方から順位を つける。この順位をそれぞれ $\left(r_{i a 1}, r_{i a 2}, r_{i b 1}, r_{i b 2}\right)$ とする。 
(b) 4 つの試料にランダムに順位をつけた場合, 生息場所 $a$ における順位の合計 $\left(r_{i a 1}+\right.$ $r_{i a 2}$ ）の期待值 $\mathrm{E}$ と分散 V は，順位に同点がなければ,

$$
\mathrm{E}\left(r_{i a 1}+r_{i a 2}\right)=5, \mathrm{~V}\left(r_{i a 1}+r_{i a 2}\right)=\frac{5}{3}
$$

となる。

(c) 全ての採集日 $(1 \sim D)$ について $\left(r_{i a 1}+r_{i a 2}\right)$ を合計したものを $X$ とする。

$$
X=\sum_{i=1}^{D}\left(r_{i a 1}+r_{i a 2}\right)
$$

$\left(r_{i a 1}+r_{i a 2}\right)$ の分布は正規分布とは異なるが，これを合計した $X$ の分布は，中心極限定 理によって正規分布に近づく。

(d) 期待値と分散は，それぞれの採集日の値の合計となる。

(e) 従って,

$$
\mathrm{E}(X)=\sum_{i=1}^{D} \mathrm{E}\left(r_{i a 1}+r_{i a 2}\right), \mathrm{V}(X)=\sum_{i=1}^{D} \mathrm{E}\left(r_{i a 1}+r_{i a 2}\right)
$$

$$
\frac{\mathrm{X}-\mathrm{E}(X)}{\sqrt{\mathrm{V}(X)}>\mathrm{z}_{a}}
$$

であれば，有意水準 $100 \alpha \%$ で生息場所 $b$ の方に多く，

$$
\frac{\mathrm{X}-\mathrm{E}(X)}{\sqrt{\mathrm{V}(X)}}<-\mathrm{z}_{a}
$$

であれば, 有意水準 $100 \alpha \%$ で生息場所 $a$ の方に多く出現したことになる。ただし $z_{a}$ は標 準正規分布の $100 \alpha \%$ 点である。

この検定法は，中心極限定理による正規近似に基礎をおいているため， $D$ の值は十分に 大きくなければならない。様々な $D$ の值に対して, $5 \%, 1 \%$ 検定を行った場合の実際の革 却率を Table B に示した。順位に同点がない場合には $D \geqq 3$ で実用上問題なくなる。各採 集日につき 1 試料だけに珪藻が出現する場合 (順位は $1,2,2,2$ となる)でも $D \geqq 7$ なら ば十分であろう。本研究でば $D=23$ なので, 目的とする珪藻が全く出現しなかった(つま ク，試料間に順位をつけられなかった）採集日が多少あった場合でも, 正規近似は有効で あると考えられる。

Table B. Actual rejection rates using the test in Table A.

\begin{tabular}{crrrrrr}
\hline Rank & \multicolumn{2}{c}{$(1,2,3,4)$} & \multicolumn{2}{c}{$(1,2,3,3)$} & \multicolumn{2}{c}{$(1,2,2,2)$} \\
\hline$D$ & $1 \%$ & $5 \%$ & $1 \%$ & $5 \%$ & $1 \%$ & $5 \%$ \\
\hline 2 & 0 & 2.8 & 0 & 2.8 & 0 & 0 \\
3 & 0.5 & 6 & 0.5 & 3.2 & 0 & 12.5 \\
4 & 0.4 & 3.9 & 0.7 & 3.2 & 0 & 6.3 \\
5 & 1.0 & 5.9 & 0.8 & 2.9 & 0 & 3.1 \\
7 & 1.3 & 5.3 & 0.8 & 5.7 & 0.8 & 6.3 \\
10 & 0.9 & 5.6 & 0.6 & 6.8 & 1.1 & 5.5 \\
15 & 1.0 & 4.4 & 0.7 & 5.2 & 0.4 & 5.9 \\
\hline
\end{tabular}


1 日の試料採集につき各生息場所の試料が 3 本以上ある場合にも，ほぼ同様の方法で検 定を行うことができる。3本ずつの試料をとつた場合，順位に同点がなければ， $D \geqq 2 て ゙$ 実 用上問題ない結果を得ることができる。またこの方法は WILCOXON 検定を二元配置に拡張 したものである。従って， $D=1$ ，かつ各生息場所の試料が各 4 本以上あるときには, WILCOXONの数表を用いて検定すればよい。

本研究では，光学顕微鏡下で同定困難な種は，種群としてまとめた。ある種群について， 生息場所間の相対優占度の有意差が検出された場合には，少なくともそこに含まれる 1 種 は，生息場所間で差があったと判断できる。また，生息場所間の相対優占度の有意差が検 出されなかった種群でも，そこに含まれる種間の相殺効果によって，生息場所間の違いが 䧮蔽されている可能性を捨てられない。 